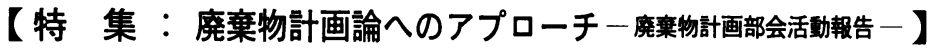

\section{廃棄物計画の動向と PFI 事業}

\author{
西 川 光 善* (事業経営・財政グループ)
}

\begin{abstract}
【要 旨】廃棄物計画の代表的なあのとして市町村が作成する一般廃棄物処理基本計画がある。本書で は, この一般廃棄物処理基本計画作成に関する最近の動向として, (1)他計画との関連, (2)社会環境の 変化, (3)ごみ処理の広域化, (4)住民参加の計画作り, (5)事業主体の有り方の 5 点を特徴的な傾向とし て取り上げて，その内容を整理している。この内容は計画作りに欠かせない視点である。次に，最近導 入され始めた清掃事業における PFI 導入について整理している。導入事例と, 導入にあたってのメ リット, 留意事項, 導入可能性調査についてコメントしている。

キーワード : 一般廃裹物処理基本計画, 住民参加, PFI 導入, PFI 導入可能性調査
\end{abstract}

1.はじめに

本書は，地球環境・資源の保全を配虑した循環型社会 構築に向けて社会全体が大きく進み始めた中で, 市町村 が作成する一般廃棄物処理基本計画策定の最近の動向と, PFI 事業の導入状況を整理した結果を報告したものであ る。

\section{2 . 一般廃棄物処理基本計画策定の動向}

一般廃棄物処理基本計画策定にあたり，最近では [1 他計画との関連，(2) 社会環境に配慮した計画策定， (3) ごみ処理の広域化, (4)住民参加の計画づくり, (5)事業 主体のあり方］が配慮されている。それぞれの動向は次 のとおりである。

\section{1 他計画との関連}

市町村が作成する一般廃棄物処理計画は, 他の行政機 関が関わる種々の計画と深い関係を持っている。一般廃 棄物処理計画体系として,「一般廃裹物処理基本計画」, 「一般廃裹物処理実施計画」,「分別収集計画」,「廃率物 循環型社会基盤施設整備事業計画」がある。一般廃棄物

原稿受付 2002.9.20

* (侏環境技研コンサルタント 専務取締役

連絡先： $\mathbf{T} 260-0001$ 千葉市中央区都町 3-14-4
処理基本計画に深い関わりを持つ計画として，環境大臣 が定める「基本方針（廃裹物処理法第 5 条の 2 第 1 項に よる)」と, 都道府県がこの基本方針に即して定める「廃 裹物処理計画」がある。また, 事業者が作成する「多量 排出事業者の減量計画」や都道府県が作成する「ごみ処 理の広域化計画」がある。それぞれの計画との整合性を 図りながら，特徵ある一般廃尧物処理基本計画を策定し ている。

\section{2 社会環境に配慮した計画策定}

一般廃棄物処理基本計画の策定にあたっては, 次に示 すような最近の廃棄物を取り巻く環境を反映した政策を 打ち出す傾向にある。[(1) 地球環境保全, 資源保全, (2) 地球温暖化防止，(3) 廃棄物の排出抑制，資源化，分別 収集, 再利用およびェネルギー資源としての有効利用 (各種関連法の反映)，(4)ISO 14001 で代表される環境 管理，監查等環境マネジメントシステム導入，(5)ょり 安全性の高い信頼性のおける処理技術を導入した施設整 備および適正な維持管理の実行， (6) 情報開示による行 政，市民，事業者の現状共通認識および合意形成，役割 分担，責務の実行，(7)排出者責任を見据えたごみ有料 化等経済的インセンティブの導入, (8) 合理的, 効率的 事業経営の推進および PFIなどの民間活力導入，(9)少 子化, 高秢化社会に対応可能な政策, (10)地方分権の推 進等] 


\section{3 ごみ処理の広域化}

ごみ処理の広域化は種々の要因により進展していない ことが多い。ごみ処理広域化計画で示される区域で，一 部事務組合か，または地域連合を早急に結成し，その地 域の一般廃率物処理計画についてソフト面を含めて，全 体で捉えなおすことが，広域化を促進する解決策の一つ になると考えられる。広域内の廃率物発生量抑制や，減 量化方策, 資源化方策, 有効利用計画, 有料化や助成措 置等のソフト面と施設整備などの八ード面を配慮し，市 民へのサービスの公平性を視点とした，地域に適合した 計画作りを行うことが望ましい。個々の市町村が独自の 廃棄物計画を立案する時代から, 広い地域での特徽を生 かした広域での廃棄物計画への時代へ移行し，広域での 循環型社会形成を目指すことが，新しい廃裹物計画づく りの視点になる。

\section{4 住民参加の計画づくり}

廃棄物計画に市民が参加することの意義は, 参加意識 が問題への関与意識を高めること, 仲間との連携意識を 生み育てること, 専門的知識を学習してより困難な問題 へ立ち向かう意識が育つこと, そして, 解決の糸口を自 ら見いだして，解決への行動を始めていくことなどとし て評価される。最近では廃棄物計画の分野でも住民の意 見を反映する手法が採用されつつある。市民が本当に必 要だとして提案する計画に対して，行政が提案された計 画が合理的で必要だと認めたときに予算をつけ，施設を 提供し，民間事業に委託する等の選択を行い，あくまで あ何をやるべきかを決めるのは住民であり，行政はサ ポートに徹するという考えである。住民参加による計画 作りは，「本当に必要な事業を着実に実施する」という 原点に戻って，あるべき清掃事業の姿を考えるいい機会 である。

市民参加による廃裹物計画づくりでの行政の役割は次 のとおりである。[1(清掃事業に関する情報の提供， (2) 具体的な計画書の作成, (3) 具体的な行動計画の明示, (4) 具体的な目標数値の提示, (5) 具体的な行動の実践, (6) 定期的な行動のチェック, 計画の見直し, 提示]市 民の役割は次のとおりである。[11清掃事業の現状と課 題の勉強, 把握, (2) 問題解決のための提案書の作成, (3)自ら実行できることの実践]市民意見の取り入れ方 には次のとおり種々の方法が考えられる。[1 ア アンケー 卜，(2)委員会形式，(3)市民愍談会形式，(4)地区愁談会， (5) 自治体職員の横断的メンバーによる検討会, (6)目的 別検討委員会方式]

市民は社会環境の変化，清掃事業の現状および抱えて いる問題を勉強する必要がある。自治体は社会環境の変
化, 清掃事業の現状および課題と考えている状況を明確 に説明する義務がある。相互の共通認識のあとで, 意見 交換を行うことにより，行政が取り組むべき姿が描かれ， おのずと，市民，事業者，行政の役割が定まる。

\section{5 事業主体のあり方}

今まで当然の如く行政が行ってきた清掃事業を, 今後 あ行政が担って行くべきか，また，PFI事業活用のよう に民間事業へとシフトして行くべきかを検討する時期に きている。一般に，2つの意見がある。1つは，清掃事 業のように大規模事業は PFIのような民間の技術や資 金を活用する手法としては，初期投資が大きく回収に時 間がかかるため，民間事業では困難であり，行政の責任 で事業実施すべきであるという意見である。他の 1 つは， 行政はできるだけ民間活力の導入を図り，部分的でもよ いので PFI 事業を導入していくべきであるという意見 である。いずれにしても，地方分権の視点から積極的な 市民参加を基軸とした政策決定手法を取り入れて，市民 から出される意見を参考に計画案をとりまとめ，その計 画の合理性，必要性を検討し，その地域に適合した事業 主体のあり方を検討することが望ましい。

\section{PFI 事業について}

ごみ処理事業に PFI (Private Finance Initiative) を導入することが行われ始めている。ここでは，PFI 導 入の事例とメリットを整理した。

\section{1 PFI 導入事例}

国内で実施されているPFI 事業（PFI 法によらない 事業も含む）には表 1 に示すようなあのがある。この中 で，実施方針の公表から契約締結などのスケジュールが 公表されているものを表 2 に示した。

\section{2 PFI 導入のメリット}

PFI 導入のメリットを整理し次に示す。

(1) ライフサイクルコストの削減

PFI (Private Finance Initiative) による初期投資 額と事業期間終了までの経費（自治体が特別目的会社 (SPC：Special Purpose Company）に支払う建設に 要する初期投資費用, 維持管理費, 運営コスト，利潤等 の総額（ライフサイクルコスト）が，通常行われる公共 事業としての総額（PSC：Public Sector Comparator （従来の公共事業を実施した場合のコスト））よりも割安 となる場合が PFI 導入の第 1 のメリットである。

PSC とPFIの LCC (Life Cycle Cost) の比較は, 
表 1 国内 PFI 事業（PFI 法によらない事業も含む）一覧（H 14. 7 時点）

\begin{tabular}{|c|c|c|c|}
\hline 事 & 例 & & 概 \\
\hline \multirow{35}{*}{$\begin{array}{l}\text { PFI 法に } \\
\text { よらないもの }\end{array}$} & \multirow{7}{*}{$\begin{array}{l}\text { 君津地域広城 } \\
\text { 発亊物処理事 } \\
\text { 業 }\end{array}$} & - 対象廃棄物 & 一般廃棄物及び条例による産業戌棄物 \\
\hline & & - 対象市町村 & 不更津市，君津市，富津市，袖ヶ浦市 \\
\hline & & ・施設規模 & 焼却施設 100 ton/旦 $\times 2$ ( I 期), 150 ton/ 日 $\times 22$ (II 期) \\
\hline & & & 発電证方 $9,000 \mathrm{kV}$ \\
\hline & & - 運転開始 & I 期は H 14 年度, III 期は H 18 年度予定 \\
\hline & & - 事業期間 & 第_I 期稼動開始から 20 年間 \\
\hline & & -事業者 & がずさリーシシステム（新日鐵，条更津市他 3 市) \\
\hline & \multirow{7}{*}{$\begin{array}{l}\text { 鹿島共同再資 } \\
\text { 源センター事 } \\
\text { 業 }\end{array}$} & - 対象廃棄物 & 一般溌棄物 (RFD) 及び産業廃棄物 \\
\hline & & - 対象市町村 & 鹿島市, 神栖町, 波崎町及び鹿島臨海工業地带 \\
\hline & & -施設規模 & 焼却施設 200 ton/日 (二廃 RDF 100 ton/日, 産廃 100 ton/日) \\
\hline & & & 発霉什力: $39,000 \mathrm{~kW}$ \\
\hline & & -運転開始 & 平成 14 年 4 月 \\
\hline & & -事業期間 & \\
\hline & & -事業者 & 鹿島共同再資源化センター（茨城県, 周辺 1 市 2 町, 三蒦化孚, 住友金属, 鹿島石油他) \\
\hline & \multirow{7}{*}{$\begin{array}{l}\text { 大牟田 RDF } \\
\text { 発電事業 }\end{array}$} & - 対象㜣棄物 & 一般廃棄物 (RDF) \\
\hline & & - 対象市町村 & 28 市町村 (福岡県内及び熊本県北部) \\
\hline & & ・施設规模 & RDF 処理量: 315 ton/日 \\
\hline & & & 発電出力: $20,600 \mathrm{~kW}$ \\
\hline & & ・運転開始 & 平成 14 年 \\
\hline & & 事業期間 & 15 年間 \\
\hline & & ・事業者 & 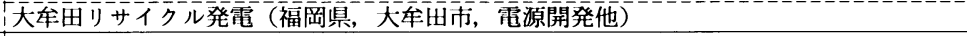 \\
\hline & \multirow{7}{*}{$\begin{array}{l}\text { 西胆振地域廃 } \\
\text { 椠物広域好理 } \\
\text { 事業 }\end{array}$} & - 対象廃裹物 & 一般廃裹物 \\
\hline & & - 対象市町村 & 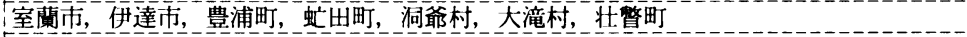 \\
\hline & & -施設規模 & 焼却施設: 210 ton/旦 \\
\hline & & & 発電出力 $1,980 \mathrm{~kW}$ \\
\hline & & ・運転開始 & 平成 15 年 4 月1日 \\
\hline & & - 事業期間 & 約 18 年間 \\
\hline & & -事業者 & 日本製鋼所，三开造船，主开物産 \\
\hline & \multirow{7}{*}{$\begin{array}{l}\text { 福山リサイク } \\
\text { ル発電事業 }\end{array}$} & - 対象廃衰物 & 一般廃棄物（RDF） \\
\hline & & - 対象市町村 & 福山市他 16 市町村 \\
\hline & & ・施設规模 & 314 ton/旦 \\
\hline & & & 発電出力: 約 $20,000 \mathrm{~kW}$ \\
\hline & & ・運転開始 & 平成16 年 4 月 (廃棄物発電施設) \\
\hline & & ・事業期間 & 15 年間 (庫共物発電施設) \\
\hline & & ・事業者 & 福山リサイクル発電(怢) (NKK, 広島県, 公社, 参画市町村) \\
\hline \multirow{28}{*}{$\begin{array}{l}\text { PFI 法に } \\
\text { よるもの }\end{array}$} & \multirow{7}{*}{$\begin{array}{l}\text { 大館周巡広域 } \\
\text { 市町村 圈 組 } \\
\text { 合・ごみ処理 } \\
\text { 事業 }\end{array}$} & - 対象廃棄物 & 一般溌棄物（産業廃棄物屯可能） \\
\hline & & - 対象市町村 & 大館市，比内町，臬代町 \\
\hline & & ・施設規模 & 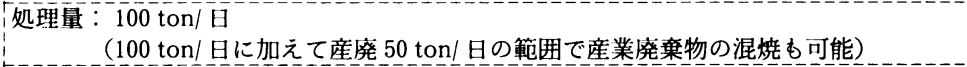 \\
\hline & & & 発電出力: \\
\hline & & ・運転開始 & 平成 15 年 4 月 \\
\hline & & - 事業期間 & 約 15 年間 \\
\hline & & -事業者 & エコマネジグループ（日立造船，丸紅） \\
\hline & \multirow{7}{*}{$\begin{array}{l}\text { 倉敷市・資源 } \\
\text { 循環型廃棄物 } \\
\text { 処理施設整備 } \\
\text { 運営事業 }\end{array}$} & - 対象咸棄物 & 一般廃棄物及び産業廃棄物 \\
\hline & & - 対象市町村 & 倉僌市 \\
\hline & & -施設規模 & 廃等の処理対象部分: 約 300 ton/旦 \\
\hline & & & 発電出力 \\
\hline & & - 運転開始 & 平成 17 年 4 月 \\
\hline & & - 事業期間 & 20 年間 \\
\hline & & ・事業者 & 水島エコワークス (川崎製鉄, 中国電力, 倉敷市, 岡山県他) \\
\hline & \multirow{7}{*}{$\begin{array}{l}\text { 彩の国資源循 } \\
\text { 環工場整備事 } \\
\text { 業 }\end{array}$} & - 対象廃棄物 & 産業廃棄物 \\
\hline & & - 対象市町村 & 県内及び県外 \\
\hline & & -施設規模 & 300 ton/旦以上 \\
\hline & & & 発電出力 \\
\hline & & ・運転開始 & 平成 18 年10月 (廃㐯物発電施設) \\
\hline & & -事業期間 & 17 年間 (廃棄物発電施設) \\
\hline & & ・事業者 & オオリッス環境グループ \\
\hline & \multirow{7}{*}{$\begin{array}{l}\text { 留辺蒠町外 } 2 \\
\text { 町一般廃棄物 } \\
\text { 最終処分場整 } \\
\text { 備及び運営事 } \\
\text { 業 }\end{array}$} & - 対象廃棄物 & 一般廃棄物不燃ごみ，不焼残さ等 \\
\hline & & - 対象市町村 & 北海道留辺賟町外 2 町 (置户町, 副子府町) \\
\hline & & - 施設規模 & 用地面皘: 約 $30.3 \mathrm{ha}$ \\
\hline & & & 埋立容量: 約 7.1 万 $\mathrm{m}^{3}$ \\
\hline & & - 運転開始 & 平成 16 年 4 月 \\
\hline & & 事業期間 & 15年間+埋立終了後水処理施設の管理 2 年間その後はSPCから自治体に施設を諒渡 \\
\hline & & -事業者 & 大成建設グループ \\
\hline
\end{tabular}

注記：既存文献および公募用入札説明書等を参考に作成。 
表 2 実施スケジュール

\begin{tabular}{|c|c|c|c|c|c|}
\hline 事業名 & スケジュール & 項 & 事業名 & スケジュール & 項 \\
\hline \multirow{12}{*}{ 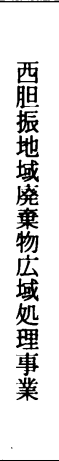 } & H 12.8.11 & 実施方針の公表 & \multirow{13}{*}{ 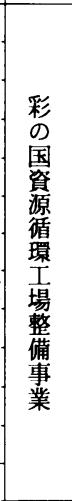 } & $\mathrm{H} 13.11 .5$ & 特定事業者の選定及び公表 \\
\hline & & 特定事業の選定の公表 & & $\mathrm{H} 13.11 .6$ & 募集要項の配布 \\
\hline & & 公告 (公募の通知) & & H 13.11 .21 迄 & 参加申込書の提出 \\
\hline & $\mathrm{H} 12.8 .14 \sim 17$ & 公募 & & H 13.11 .30 迄 & 応募資格の確認通知 \\
\hline & $\mathrm{H} 12.8 .18$ & 入札資格審查結果の通知, 募集要項配布 & & $\mathrm{H} 13.12 .7$ & 第 1 回質問書の受付 \\
\hline & $\mathrm{H} 12.9 .11$ & 見積設計図書, 見積書提出 & & H 13.12 .20 迄 & 第 1 回回答書の配布 \\
\hline & $\mathrm{H} 12.9 .29$ & 技術評価の認定通知 & & $\mathrm{H} 14.1 .10$ & 第 2 回質問書の受付 \\
\hline & $\mathrm{H} 12.10 .11$ & 見皘書の開札＿コスの妥当性番査，優先交涉権者決定 & & H 14.1 .23 迄 & 第 2 回回答書の配布 \\
\hline & $\mathrm{H} 12.10 .17$ & 契約交渉 & & $\mathrm{H} 14.2 .4 \sim 7$ & 提案書の提出 \\
\hline & H 13.1 .15 & 契約の締結 (基本協定, 工事請負, 施設運転保守管理委) & & H 14.3 .29 & 審查結果通知 \\
\hline & $\mathrm{H} 15.3 .31$ & 施設竣工 & & $\mathrm{H} 14.3$ & 優先交渉権者の選定 \\
\hline & H 33. 3. 31 & 事業契約終了 & & $\mathrm{H} 14.11$ & 仮契約の締結 \\
\hline \multirow{8}{*}{$\begin{array}{l}\text { 福 } \\
\text { 山 } \\
\text { リ } \\
\text { サ } \\
1 \\
ク \\
\text { ル } \\
\text { 発 } \\
\text { 電 } \\
\text { 業 }\end{array}$} & H 12.5 & 事業会社設立 & & H 14.12 & 本契約の締結 \\
\hline & $\mathrm{H} 13.10$ & フコイナンスアレンジメント等開始 & \multirow{6}{*}{$\begin{array}{l}\text { 留 } \\
\text { 藥 } \\
\text { 外 } \\
\text { N } \\
\text { 町 }\end{array}$} & H 13.10.12 & 実施方針の公表 \\
\hline & $\mathrm{H} 13.11$ & 建設 (仮) 契約 & & $\mathrm{H} 13.10 .12 \sim$ & 実施方針に対する意見の受付 \\
\hline & $\mathrm{H} 14.2$ & 事業会社增資 & & $\mathrm{H} 13.10 .19$ & 特定事業選定の公表 \\
\hline & H 14. 3 & FDF 長期供給契約 (処理契約) 締結 & & H 13.10 .22 & 入札公告及び入札説明書等の交付 \\
\hline & $\mathrm{H} 14.11$ & 事業関連契約締結 & & $\mathrm{H} 13.10 .29$ & 入札説明書等に関する第 1 回質問受付 \\
\hline & $\mathrm{H} 14.11$ & ファイナンス契約締結 & & $\mathrm{H} 13.11 .12$ & 入礼説明書等に関する第 1 回質問に対する回答 \\
\hline & H 16.4 & 施設稼働 & \multirow{13}{*}{ 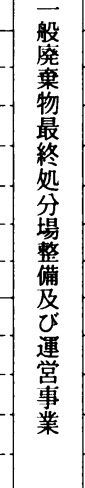 } & $\mathrm{H} 13.11 .29$ & 参加資格確認結果の通知 \\
\hline \multirow{7}{*}{$\begin{array}{l}\text { 大組 } \\
\text { 䝯合 } \\
\text { 边 } \\
\text { 広 } \\
\text { 域処 } \\
\text { 帝理 } \\
\text { 町 事 } \\
\text { 标 } \\
\text { 業 }\end{array}$} & $\mathrm{H} 12.12 .25$ & 実施方針 & & $\mathrm{H} 13.11 .30$ & 入札説明書等に関する第 2 回質問受付 \\
\hline & $\mathrm{H} 13.1 .16$ & 特定事業の選定 & & $\mathrm{H} 13.12 .14$ & 入柇説明書等に関する第 2 回質問に対する回答 \\
\hline & $\mathrm{H}$ 13.1.17 & 募集要項の公表 & & $\mathrm{H} 14.2$ & 落札者（事業予定者）決定 \\
\hline & $\mathrm{H} 13.3 .28$ & 入札 & & $\mathrm{H} 14.2$ & 基本協定締結 \\
\hline & $\mathrm{H}-13.3 .29$ & 落札者の決定 & & $\mathrm{H} 14.5$ & 仮契約の締結 \\
\hline & H 13.6 末 & 契約の締結 & & $\mathrm{H} 14.6$ & 事業契約の締結 \\
\hline & H $15.4 \sim$ & 供用開始 & & H $14.8 \sim$ & 建設工事 \\
\hline \multirow{5}{*}{ 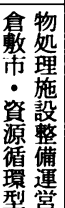 } & $\mathrm{H} 13.5 .15$ & 事業実施方針の公表 & & $\mathrm{H} 16.4 \sim$ & 施設の運営・管理（埋立廃积物の受入） \\
\hline & $\mathrm{H} 13.5 .30$ & 特定事業者の選定及び公表 & & $(15$ 年間) & \\
\hline & $\mathrm{H} 13.7 .3$ & 入札公告 & & $\mathrm{H} 31.4 \sim$ & 施設（水質を含む）の管理等 \\
\hline & $\mathrm{H} 13.11 .30$ & 事業者の決定 & & $(2$ 年間 $)$ & \\
\hline & $\mathrm{H} 14.1$ 初 & 契約の締結 & & H 33.4 & 施設の詨渡 \\
\hline
\end{tabular}

注記：既存文献および公募用入札説明書等を参考に作成。

VFM (Value For Money)により行う。従来方式での 公共事業の事業期間全体を通じた公的財政負担の見込 額 (PSC) の現在価値 (NPV: Net Present Value) と PFI 事業として実施する場合の事業期間全体を通じた公 的財政負担の見込額の現在価値を比較することにより算 出する。まず, PFI 事業においてはPFI 事業者や公共 事業の請負事業者からの税収（事業委託者が受けとる税 収）をそれぞれ控除し，PSCについては公共側が負担 しているはずのリスク調整值を経験值等から算出し, こ れを加算するなどの調整を行って将来見込まれる公的財 政負担の総額を算出する。その後, これを一定の割引率 で現在価値に換算した後, 評価を行う。

VFM がある : PSC >PFI 事業の LCC

VFM がない：PSC < PFI 事業の LCC

PFI 導入の場合, 施設規模, 建築仕様, 維持管理体制 などを SPCのノウハウにより自由裁量によって一定レ
ベルのサービスを購入できるようにすることがこのメ リット（VFM）を引き出すポイントとなる。

(2) 費用の平準化

公共事業として行う場合, 初期に工事費として多額の 出費が必要となるが, PFI 事業として行う場合, 事業期 間を通じた総費用を平準化した形で支払いを計画でき, 財政の一時的な圧迫を避けることができることがメリッ トとしてあげられる。

なお，自治体にとって事業期間終了後，仮にその施設 がまだ利用でき，継続して利用するとした場合，事業期 間中に建設に要する初期投資費用はすでに回収されてい るため, その後に支払う経費は理論的には改修費と維持 管理費, 運営管理費, 利潤等だけとなり, 費用低減が図 られることも想定される。

(3) 効率的な運営

民間企業による事業経営の利点として, 行政での単年 
度予算主義などで制約を受けることがなく，長期的な見 通しの下で比較的緩やかな運営ができ, 柔軟な経営によ る効率的な投資効果を得る事ができることがメリットと してあげられる。

(4) 施設建設の工期短縮・迅速化

民間企業が施設建設を行うことにより, 調査, 設計, 工事が国の予算や，執行時期などの制約を受けることな く独自に推進でき，工期の短縮・迅速化ととあにコスト ダウンを図ることができることがメリットとしてあげら れる。

\section{3 PFI 導入にあたっての留意事項}

PFI 導入にあたり, 次の事項について留意する必要が ある。

(1) SPC の事業途中でのデフォルト

SPC は民間企業であるため，契約時に種々想定した リスクを超える事態が出現した場合，事業途中で経営が 成り立たなくなり，事業放棄をする場合がないとはいえ ない。このため，そのような事態にも対応できるような 実績と信頼のおける出資会社を選定することに留意する 必要がある。

また，デフォルト時においては事業を引き継ぐ事業会 社を予め契約により決めておき，事業を継続できる体制 を整備しておくことも重要である。

\section{(2) 事業内容の自由度}

PFI 導入のメリットは，第 1 に費用投資効果を最大限 に生み出すことといえる。このため，自治体が示す事業 の仕様は, できる限り, SPCのノウハウが発揮できる ように自由度を極力大きくし，サービス水準を維持また は向上した上で PSCに比べ安いコストでサービスを購 入できるようにする必要がある。たとえば，建設時点で の施設規模（稼働日数の捉え方により規模縮小が可能な 場合がある。）や，予備の考え方，建屋の範囲や仕様，さ らには, 維持管理時点での維持管理体制, 薬品等の仕入 れの方法などに自由度を与え，当初目的である事業が効 率的に達成できるようにする必要がある。

(3) PFI 事業プロセスでの外部アドバイザー

PFI 導入にあたっては, PFI 事業実施プロセスのガイ ドラインに定める方式に沿って事業を進めることになる。 そのプロセスは表 3 のとおりである。

この事業プロセスで，通常の公共事業と異なるのはス テップ 5 の協定等の締結等の段階で綿密な協議が必要と なることである。当事者双方の負う債務の詳細および履 行方法等や，適正なサービスを担保するための規定，リ スク配分の適正化，委託料等の支払方法，契約解除に関 する規定，協定料等の解釈に疑義が生じた場合の規定等
表 3 PFI 事業のプロセス

\begin{tabular}{|c|c|c|}
\hline I & ステップ & 主な作 業 \\
\hline \multirow[t]{3}{*}{ 特定事業の選定 } & 1. 事業の発案 & $\begin{array}{l}\text { ・事業を検討する際の } \\
\text { 体制づくり } \\
\text { ・PFI 事業の可能性調 } \\
\text { 查の実施 }\end{array}$ \\
\hline & $\begin{array}{l}\text { 2. 実施方針の策定及び } \\
\text { 公表 }\end{array}$ & $\begin{array}{l}\text { - 実施方針の策定 } \\
\text { - 公表 }\end{array}$ \\
\hline & $\begin{array}{l}\text { 3. 特定事業の評価・選 } \\
\text { 定, 公表 }\end{array}$ & $\begin{array}{l}\text { - 評価・選定 } \\
\text { - 公表 } \\
\end{array}$ \\
\hline \multirow[t]{2}{*}{$\begin{array}{l}\text { 民間事業者の募 } \\
\text { 集及び選定等 }\end{array}$} & $\begin{array}{l}\text { 4. 民間事業者の募集, } \\
\text { 評価, 選定, 公表 }\end{array}$ & $\begin{array}{l}\text { - 募集 } \\
\text { - 評価・選定 } \\
\text { - 公表 }\end{array}$ \\
\hline & 5. 協定等の締結等 & $\begin{array}{l}\text { - SPC との協定 } \\
\text { - 金融機関との協定 } \\
\text { - 公表 }\end{array}$ \\
\hline \multirow[t]{2}{*}{ PFI 事業の実施 } & 6. 事業の実施, 監視等 & $\begin{array}{l}\text { - 事業の監視 } \\
\text { ・監視結果の公表 }\end{array}$ \\
\hline & 7. 事業の終了 & - 資産の処理 \\
\hline
\end{tabular}

表 4 リスク分担項目例

\begin{tabular}{|c|c|}
\hline 1. 全期間 & $\begin{array}{l}\text { (1)制度・法令変更リスク, (2)政治リスク, } \\
\text { (3)物価変動リスク, (4)金利変動リスク, } \\
\text { (5)住民合意リスク, (6)デフォルトリス, } \\
\text { (7)用地確保リスク, (8)事業の中止・延期, } \\
\text { (9)不可抗力, (10関連インフラの整備リス } \\
\text { ク, (11)産業廃棄物リスク }\end{array}$ \\
\hline 2. 事業条件整備段階 & $\begin{array}{l}\text { (1)用地使用件リスク，(2)環境アセスメン } \\
\text { トリスク }\end{array}$ \\
\hline 3. 計画段階 & $\begin{array}{l}\text { (1)測量・調查リスク, (2)設計リスク, (3)計 } \\
\text { 画変更・遅延リスク，(4)資金調達リスク }\end{array}$ \\
\hline 4. 設設段階 & $\begin{array}{l}\text { (1)夕イムオーバーランリスク, (2)コスト } \\
\text { オーバーランリスク }\end{array}$ \\
\hline 5. 運営段階 & $\begin{array}{l}\text { (1)供給リスク, (2)性能リスク, (3)運営コ } \\
\text { ストリス，(4)設設損傷リスク }\end{array}$ \\
\hline
\end{tabular}

（倉敷市・資源循環型廃棄物処理施設整備運営事業実施方針より）

について協議する。通常の公共事業の場合は契約約款な どの確認ですむが，PFI 事業の場合は，リスク配分など について双方の協議が必要となる。リスクについては表 4 に示すようなあのがあげられる。

この協議ステップに際して，地方自治体，SPC，金融 機関，保険会社のほかに双方とあ外部アドバイザーとし て, 弁護士, 会計士, コンサルタント, シンクタンクな どの専門的な知識を有する者を参画させている。これら 費用の発生が通常公共事業には見られないあのである。 図 1 にPFIの基本的な事業スキームを示した。

\section{4 PFI 導入可能性調査について}

PFI 導入可能性調查として，事前に事業の概略仕様を 定め, この概略仕様に沿って, 事業提案をとり, 概略的 なVFM を求めることが必要となる。この作業は，施設 整備計画作業と平行して実施することが可能である。

この PFI 導入可能性調查により，市が考えているご み処理施設整備運営事業について PFI 導入による VFM 


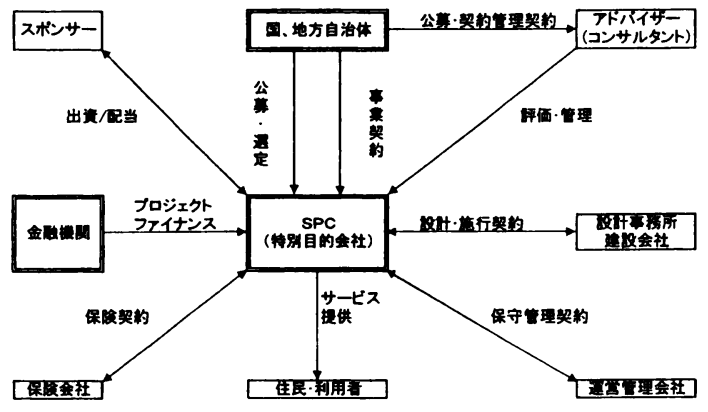

図 1 PFI の事業スキーム

があると判断されるかどうかの検討を行う必要がある。 また，事業形態についてあ 100\% 民間出資による事業体 とする場合, 第 3 セクター方式の方法, さらに, 役割分 担方式（部分的に民間委託する方式：すでに多くの自治 体で取り入れられている）の場合の 3 方式が考えられる。 その場合の, 事業に対する自治体の費用負担, 住民から の信頼性, リスク分担, サービス水準などについて比較 検討する必要がある。

\section{4.おわりに}

廃棄物処理事業を具体化するためには, まず, その地 域での廃棄物計画づくりが最初に取り組むべき作業とな る。この作業がスムーズに行けば, 計画された個々の作 業項目の必要性が市民, 事業者, 行政において認識され, あとは, 何を, いつ, 何処で, 誰が, どのような方法で, どのような財源で実行に移すかを検討すればよい。

本書では, 事業化の検討のうちの最初の段階である, 循環型社会形成のために市町村が策定する一般廃棄物処 理計画はどのような動向であるかを整理するとともに, PFI 事業の導入の実態を整理している。今後は, 廃棄物 計画策定の姿について検討を進めるとともに, PFI 事業 の導入検討方法についても検討を重ねたいので, 種々の 視点から見た意見をお寄せいただきたい。なおここで 記載した廃棄物計画の動向は, 平成 14 年廃棄物学会春 の小集会で発表したものである。

\title{
Waste Management Plan as an Exemplary Project to be Conducted by Local Governments
}

\author{
Mitsuyoshi Nishikawa \\ Managing Director, Kankyougiken Consultant Co., Ltd. \\ (3-14-4 Miyako-Cho, Chuoku, Chiba, 260-0001 Japan)
}

\begin{abstract}
The following significant trends regarding waste management and treatment strategies must be taken into consideration: 1) Networking between various projects; 2) Changes in social attitudes about the environment; 3 ) Extension of waste treatment areas; 4) Participation of citizens in planning; and 5 ) Position of local governments. The content of these points are indispensable to the creation of a waste management plan, and are explained in detail in this study. In addition, the PFI system which has been introduced with regard to waste management procedures, is also explained. Some examples of where it has been introduced, its merits, points for consideration, and feasibility studies for its introduction are included.
\end{abstract}

Key words : waste management plan, public/citizen participation, introduction of PFI, feasibility studies for PFI 